\title{
Why China Survived the Asian Financial Crisis?
}

\author{
Por que a China sobreviveu à crise financeira asiática?
}

SHALENDRA D. SHARMA*, ${ }^{1}$

RESUMO: A economia chinesa mostra uma notável semelhança com as da Tailândia, Indonésia, Coreia do Sul e Malásia antes da crise - especialmente as bolhas de ativos, alta dependência de intermediação bancária, má supervisão prudencial e fragilidade do sistema financeiro. No entanto, a China desafiou a previsão comum e não sucumbiu à crise financeira. O que explica a capacidade da China de suportar uma grande crise financeira em toda a região? Este estudo aborda essa questão complexa, além de elaborar as medidas de reforma que a China deve implementar para se imunizar contra futuras crises financeiras ou seus efeitos de contágio.

PALAVRAS-CHAVE: China, Leste da Ásia, crises financeiras.

ABSTRACT: The Chinese economy shows a remarkable resemblance to those of pre-crisis Thailand, Indonesia, South Korea and Malaysia - especially the asset bubbles, high reliance on banking intermediation, poor prudential supervision, and fragility of the financial system. Yet, China defied the common prediction and did not succumb to the financial crisis. What explains the China ability to withstand a major region-wide financial crisis? This study addresses this complex question, besides elaborating the reform measures China must implement to immune itself from future financial crises or its contagion effects.

KEYWORDS: China, East Asia, financial crises.

JEL Classification: O53. O57.

When the financial crisis unexpectedly hit the high-performing East and Southeast Asian economies in mid-1997, it was widely believed that the Peoples Republic of China (PRC) would be the next domino to fall. China's extensive intra-regional trade and investment linkages with the rest of Asia, and the fact that the Chinese

* Ph.D, is associate professor of political economy and director of the Master of Arts in Asia-Pacific Studies at the University of San Francisco. E-mail: shalendrasharma@ln.edu.hk; Orcid: 0000-00025091-9248.

${ }^{1} \mathrm{He}$ is also consultant to the International Monetary Fund. 
economy suffers from many of the same debilitating structural problems that long plagued (and ultimately did incalculable damage) to the Republic of Korea (South Korea), Thailand, Malaysia and Indonesia — namely, fragile bank-dominated financial systems, poor prudential surveillance and weak central bank regulation and supervision of commercial banks, a large buildup of non-performing loans due in part to excessive lending to inefficient, over-leveraged state enterprises, and a largely state-owned financial sector that may be almost insolvent — led many observers to conclude that the contagion's virulent spread to China was imminent. ${ }^{2}$

However, the middle-kingdom beat the odds. Although the Asian flu effected China on both its external trade account and external capital account, nevertheless, like the Great Wall, China not only remained conspicuously insulated from the region-wide financial meltdown of unprecedented severity, the mighty dynamo fueling its economy missed only a few beats during the crisis and since. ${ }^{3}$ China's ability to sustain a strong gross domestic product (GDP) growth performance of $8.8 \%$ in 1997 and $7.8 \%$ in 1998 and over $8.0 \%$ in $1999,{ }^{4}$ continued success in attracting foreign direct investment $(\mathrm{FDI})^{5}$ and in running healthy current account surpluses (roughly $3 \%$ in 1998-99), and maintaining the stability of its currency, the RMB (renminbi), in the face of plummeting currency devaluations and precipitous asset price deflation elsewhere in the region and beyond, is simply miraculous. ${ }^{6}$ In a region where China's intentions are viewed with much suspicion, the PRC's handling of the crisis has earned it much plaudits. Chuan Leekpai, the Prime Minister of Thailand has, on more than one occasion publicly thanked China for maintaining the value of the renminbi and for contributing US\$1 billion to the IMF

\footnotetext{
${ }^{2}$ For an overview of the Asian financial crisis see Shalendra D. Sharma, "Asia's Economic Crisis and the IMF”, Survival: IISS Quarterly, vol. 40, n² 2, Summer 1998: 27-52.

${ }^{3}$ On the trade account, much-depreciated currencies and plummeting incomes in Southeast Asia hurt China's exports. On the capital account, foreign investment dried up, particularly from Hong Kong, China's main source of foreign investment.
}

${ }^{4}$ See, Asian Development Bank. Asian Development Outlook, 1999 (Washington, D.C.: Oxford University Press, 1999: 5). It is important to note that the official PRC figure for 1998 GDP measured in current yuan is 7.95 trillion. Measured in U.S. dollars, using the IMF's average exchange rate for 1998 (8.28 yuan \$1), China's 1998 GDP was \$961 billion.

${ }^{5}$ In 1997 foreign direct investment rose for the seventh consecutive year to reach US\$45.3 billion. This is in addition to the US\$16 billion in debt and equity offerings China raised in international markets. Moreover, official holdings of foreign exchange reserves increased in 1997, reaching US\$140 billion by year-end, second in size only to Japan. Data compiled from the Chinese government's, State Statistical Bureau. Economic Statistical Communique (Beijing: China Statistical Publishing House, March 4, 1998). Also, Foreign Broadcast Information Service, China Daily Report, March 12, 1998.

\footnotetext{
${ }^{6}$ China's nominal exchange rate vis-a-vis the U.S. dollar (RMB 8.3 to the dollar) has been virtually unchanged since early 1995 . Encouraging Chinese currency stability was critical at the height of the Asian crisis since a devaluation of the yuan could have set off a wave of additional competitive devaluations and a further downward economic spiral in the region. Also, in sharp contrast, by late 1997, in US\$ terms, the Indonesian rupiah was worth only one-fifth of its June 1997 value, while the Thai babt and the Korean won lost around half their former values. The Philippines peso and the Malaysian ringgit fell some 40 percent below pre-crisis values.
} 
package for Thailand. Similarly, Singapore's minister for information, the indefatigable George Yeo, while accusing Japan of abdicating its global responsibilities, noted that "the determination of the Chinese government not to devalue the renminbi in order not to destabilize Asia further will long be remembered" 7 .

How has China responded to the Asian financial crisis? Why has China come through such a severe region-wide economic contraction relatively unscathed? What explains the resilience of the Chinese economy, and can the PRC continue to remain insulated from the uncertainty that still pervades the region and beyond? What lessons can be learned from China's experience? And, what policy measures must China implement to further insulate itself from the seemingly unpredictable (and volatile) international financial and currency markets. The following sections discusses these interrelated issues. The core argument is that China's handling of the crisis, in particular, the country's ability to withstand the crisis, must be understood within the context of its domestic political economy. While it was arguably in China's interest not to devalue the RMB during the height of crisis, there are forces at work within the economy that may force China to rethink the strategy in the future.

\section{THE ECONOMY: UNDERLYING STRENGTHS}

Never in recorded history has an economy grown so rapidly and as extensively as that of post-Mao China. The Third Plenum of the Eleventh Communist Party Congress in December 1978 saw the rise of the late Deng Xiaoping as the paramount leader and the launching of his pragmatic economic program aimed at ostensibly creating a "socialist market economy with Chinese characteristics". Between 1978 and 1995-96, the PRC's economy grew at an unprecedented average rate of $9.5 \%$ per year, notching up an all time high of $14.2 \%$ growth rate of GDP in 1992. China's gross national product (GNP) has more than quadrupled since the early 1980s. The additional 20\% to China's GDP on July 1, 1997 when Hong Kong became a Special Administrative Region of the Peoples Republic was a bonus. China's rapid transformation into a veritable 'dragon economy' is reflected in the fact that based on purchasing power calculations it is currently the second largest economy after the United States, a far cry from the bottom rungs of the economic development ladder it occupied less than two decades ago. ${ }^{8}$

Market-oriented policies epitomizing Deng Xiaoping's gradualist strategy of "crossing the river by groping for stepping-stones" has been the catalyst behind

\footnotetext{
${ }^{7}$ Paul Kelley, “Great Stumble Forward”, The Weekend Australian, April 25-26, 1998: 28.

${ }^{8}$ For an excellent overview, see Nicholas R. Lardy, China in the World Economy (Washington, D.C.: Institute for International Economics, 1994); Nicholas R. Lardy, China's Unfinished Economic Revolution (Washington, D.C.: The Brookings Institution Press, 1998) and Elizabeth Economy and Michel Oksenberg, China Joins the World: Progress and Prospects (New York: Council on Foreign Relations Press, 1999).
} 
China's phenomenal economic growth. Specifically, the devolution of government authority from the central to sub-national or local governments (the latter including provinces, prefectures, counties, townships, municipalities and villages) helped spur economic expansion. In their seminal paper, Montinola, Qian and Weingast (1995) called this "Federalism, Chinese Style". ${ }^{9}$ That is, the Chinese style federalism was fundamentally "market-preserving federalism." By devolving regulatory authority from the central to the local governments, the interventionist role of the central government was limited. The theory provides two possible mechanisms for aligning local governments' interest with promoting markets. One is through interjurisdictional competition under factor and goods mobility to discipline interventionist local governments. That is, decentralized control over the economy by subnational governments within a common market prevents the central government from interfering in markets. Another is through linking local government expenditure with the revenue generated to endure that the local governments face the financial consequences of their decisions. Moreover, inter-governmental competition over mobile sources of revenue constraints individual sub-national governments.

It should also be noted that the devolution of authority in the PRC was also accompanied by the provision of fiscal incentives, and local governments were encouraged and rewarded by promoting the development of their local economies. For example, the formal budgetary revenue starting in 1980, the "fiscal contracting system" known by the nickname of "eating from separate kitchens" replaced the previous system of "unified revenue collection and unified spending" known as "eating from one big pot". Under the new fiscal system local governments entered into long-term (usually five-year) fiscal contracts with higher level governments, and many were allowed to retain $100 \%$ at the margin to make them "residual claimants". In addition, local governments also received "extra-budgetary funds" which were not subject to sharing, not to mention the "off-budget funds" which were not even incorporated into the budgetary process and thus not recorded.

It is well known that agricultural reform was the first reform success in the PRC. In the countryside, the de-collectivization of agriculture, the restoration of rural markets and the changes in the grain procurement system - indeed, the complete replacement of the decrepit and corruption-ridden agricultural collectivization system with the incentive based "household responsibility system" in 1979 is seen by many as key to China's economic success. ${ }^{10}$ For example, according to

\footnotetext{
${ }^{9}$ Gabriella Montinola, Yingyi Qian and Barry Weingast, "Federalism, Chinese Style: The Political Basis for Economic Success in China”, World Politics, 48 (1) October 1995: 50-81.

${ }^{10}$ By March 1956, over 90 percent of peasants were in collectives, and by 1957, almost all were in advanced producers' collectives. See, Christopher Howe, China's Economy: A Basic Guide. (New York: Basic Books, 1978). Unlike the collectivized system, under the household responsibility system farmland is contracted out to individual families who enjoy autonomy in regards to the production and marketing of crops. After paying (either in cash or kind), taxes to the government and contract fees to the village (which still owns the land), the family is largely free to consume or sell what it produces. In 1995, land contracts which had been set at fifteen years was extended for another thirty years in 1999 in order to
} 
Jean Oi, the household responsibility system which transferred the income rights over agricultural production from collectives to individual households, significantly enhanced the production incentives of peasants, while depriving local governments of a major source of income. At the same times, China's fiscal reform granted local governments the right to retain part of the extra tax revenue they raised. In other words, the higher the rate of economic growth, the higher the tax revenue, and the greater the income of local governments. Given such an important stake in economic growth, local governments were motivated to mobilize resources under their jurisdiction to engage in entrepreneurial activities. They established and ran rural enterprises and took the profits to pay for expenditures and reinvestment. Thus the development of what Oi calls "local state corporatism" - under which local governments functioned like a large corporation with diversified businesses - served as the engine of China's economic development. Oi compelling argues that local state corporatism explains why China has been able to achieve rapid economic growth without privatization and why state officials have not been resistant to reform. ${ }^{11}$

The Chinese political leadership have long viewed agriculture as the foundation of the economy. This is hardly surprising given the fact the country has $22 \%$ of the world's population, but only $7 \%$ of its arable land, and that some 800 million people still live in rural communities. China's economic reforms began in agriculture in the late 1970s. Because this sector had been heavily repressed under central planning, its liberalization had immediate payoffs. Specifically, the adoption of the household responsibility system resulted in an immediate and dramatic increase in agricultural production and productivity. Between 1981 and 1984 agriculture grew on average by $10 \%$ a year generating higher rural savings and investment, and the release and reallocation of labor for employment in agriculture and in the emerging rural industries. ${ }^{12}$ The agricultural growth was critical because by mid-1975, the per capita consumption of grain, cooking oil and meat protein was lower than it had been in the 1950 s, and malnutrition and hunger a growing problem. ${ }^{13}$ Indeed, under Maoist collectivism (1952-78), total agricultural factor productivity fell sharply, and rural per capita incomes grew only by an average of only $0.5 \%$ between 1957 to 1977 — not including the estimated 16.5 million to 29.5 million

give farming families more stability in planning their production and investment. This was supported by a policy to enlarge private plots and to purchase a fixed proportion (around $20 \%$ ) of the harvest at above market prices. For an excellent overview, see Justin Lin, "Rural Reforms and Agricultural Growth in China", American Economic Review, 82, no. 1 March 1992: 34-51.

11 Jean Oi, "Fiscal Reform and the Economic Foundations of Local State Corporatism in China", World Politics, vol. 45, October, 1992.

12 For details see, World Bank, World Development Report, 1996. New York: Oxford University Press, 1996: 20-21.

${ }^{13}$ Robert F. Dernberger, “The People's Republic of China at 50: The Economy” The China Quarterly, no. 159, September 1999: 609 . 
people who perished during the ill-fated Great Leap Forward. ${ }^{14}$ In sharp contrast, during the post-Mao era the agricultural sector (measured in terms of farm output) has grown consistently at the impressive rate of $6 \%$ per year. Net rural incomes have risen from less than 150 yuan in 1978 to roughly 400 yuan in 1985, and reached approximately 2,000 yuan by $1997 .{ }^{15}$ In real per capita terms, rural incomes increased by $63 \%$ between 1985 and 1997.16 This has led to a significant improvement in the living standards of China's peasants who have seen their consumption increase at an annual rate of $7.8 \%$ per annum between $1979-92 .{ }^{17}$ Agricultural growth has also provided the surplus needed to sustain the rapidly expanding industrial base and the growing urban population.

The initial success of the rural reforms encouraged the government to broaden reforms to include the urban-industrial sectors in 1984, and to gradually dismantle the central planning system. In the industrial sector important reform measures implemented included experiments to grant state enterprises more autonomy in production and employment decisions (the contract responsibility system), the extension of the dual track system to industrial prices and the introduction of enterprise taxation. In sharp contrast to most developing nations, China's handling of surplus or the so-called 'floating' rural labor (estimated to be between 120-140 million persons) made redundant as the result of gains in agricultural productivity, has been impressive. In 1984, as the central government decentralized fiscal power and allowed provincial and local governments to retain and reinvest locally generated revenues, it created a powerful incentive for the development of local businesses. To meet this demand, the government astutely encouraged the development of rural township and village enterprises $\left(\mathrm{TVEs}^{18}\right)$. Although still predominantly collectivelyowned, the TVEs had a big advantage over their competitors, namely the stateowned

\footnotetext{
${ }^{14}$ For an excellent overview of agricultural stagnation during the Mao period, see Justin Lin, "Collectivization and China's Agricultural Crisis in 1959-61", Journal of Political Economy, 98, December (1990): 1228-52.

${ }^{15}$ Guojia Tongi Ju (GTJ), Zhongguo Tongji Nianjian 1998 (China Statistical Yearbook 1998), Beijing: Zhongguo Tongi Chubanshe, 1998: 345

${ }^{16}$ Albert Nyberg and Scott Rozelle, “Accelerating China's Rural Transformation”, World Bank Working Paper Series, Washington D.C., 1999.

${ }^{17}$ Data is from Raghu Nath and Qingjiu Tao, "Economic Transition Strategies of China”, paper presented at conference, "China, India and Russia: Progress in Challenges of Economic Transition", Michigan State University, East Lansing, October 23-25, 1998, and Guojia Tongji Ju (GTJ), Zongguo Tongji Nianjian 1993 (Statistical Yearbook of China 1993), Beijing: Zhongguo Tongi Chubanshe, 1993: 46. Also see, Bill Brugger and Stephen Reglar. Politics, Economy and Society in Contemporary China (Stanford: Stanford University Press, 1994).

18 TVEs can be classified into two types. The first, the collectively owned enterprises (township-run or village-run enterprises) are owned by the local government and operates like a holding company, reinvesting profits in existing or new ventures, including local infrastructure. The second, and more recently developed type is much closer to private enterprise in that most are controlled, if not informally owned by an individual. Nevertheless, both types maintain close fiscal ties to the local and provincial governments.
} 
enterprises (SOEs). The TVEs operated free from government restraints, were not subject to any planning targets, were responsible for their own profits and losses, and could by inputs and sell products freely wherever there was demand, including on export markets. ${ }^{19}$ The majority of TVEs are small and medium-sized firms and their products are generally labor-intensive in nature. Currently, TVEs dominate the building materials and agricultural machinery industries, including textiles and garments, processed foods and beverages, and coal and cement. Increasingly, TVEs account for growing share of the production of electronics and telecom equipment. The growth and performance of the TVEs has been extraordinary. The TVEs have grown from 1.52 million in 1978 to roughly 23 million in $1996 .{ }^{20}$ Owned by local government, private citizens, and other local enterprises, the TVEs share in GDP have risen from $13 \%$ in 1985 to $31 \%$ in 1994 . Output has grown by some $25 \%$ a year since the mid-1980s, and in 1996 the TVEs accounted for a third of total industrial growth in China, besides creating 130 million jobs between 1980-1996 B absorbing nearly $30 \%$ of the 450 million laborers in the countryside. ${ }^{21}$

Central to China's economic growth has been the liberalization of the foreign trade and investment regime, and the adoption of an ambitious "open-door" strategy. Prior to the introduction of the Deng reforms, China remained a backward and closed economy, with foreign trade amounting to a minuscule $7 \%$ of GNP. However, the liberalization of the foreign trade and exchange rate regime, followed by further wide-ranging reforms introduced in 1988 (which included increased retention of foreign exchange and easier access to foreign exchange adjustment centers established in 1986), enabled businesses (i.e. the enterprises) to buy and sell foreign exchange at a depreciated rate known as swap rate greatly helped to boost exports. Not surprisingly, by the early 1990s, foreign trade had grown to an unprecedented $\$ 200$ billion or roughly $40 \%$ of GNP. ${ }^{22}$

Before 1994, liberalization of foreign exchange markets followed a dual-track approach in that there existed an official rate and a "swap rate" (i.e. the market rate). On 1 January 1994 China unified its exchange rate by bringing the official rate into line with the prevailing swap-market rate, resulting in the depreciation in the official rate by about $50 \%$ (i.e. the yuan was devalued by $50 \%{ }^{23}$ ). China's

\footnotetext{
${ }^{19}$ In contrast, the SOEs had the advantage of captive markets and government support, but also remained subject to heavy government intervention, state pricing and the obligation to provide social support services.

${ }^{20}$ Susumu Yabuki and Stephen Harner, China's New Political Economy. Boulder, CO.,: Westview Press: $143-44$.

${ }^{21}$ World Bank, World Bank Development Report, 1996. New York: Oxford University Press, 1996: 5051; Yabuki and Harner: 144.

22 Valerie Cerra and Anuradha Dayal-Gulati, “China's Trade Flows: Changing Price Sensitivities and the Reform Process” IMF Working Paper 99/1, 1999.

${ }^{23}$ At the time the official rate of the RMB was at 5.8 RMB per US dollar versus the 8.7 RMB per dollar at the swap center.
} 
preemptive devaluation, even as it led to a real exchange appreciation for the dollar pegged currencies in Southeast Asia (significantly undercutting their export competitiveness), created an export boom for China. ${ }^{24}$ Moreover, reform measures such as the (a) abolishment of the retention quota system for foreign exchange, (b) the revision of the tax system to allow a zero value-added tax (VAT) rating for exports by domestic firms and the newly established foreign-funded enterprises, ${ }^{25}$ (c) further relaxation of China's open-door policy towards foreign direct investment, including the provision of special tax incentives to foreign investment in technologyintensive industries, and (d) generous tariff concessions (including lower income tax rates and tax holidays) to firms operating in the coastal special economic zones only served to further enhance China's international competitiveness and helped it to greatly expand its export markets. Between 1990-1997, Chinese exports to industrialized countries has grown at an average rate of $15.5 \%$ per annum, and for the period 1995-1997 which saw a decline in world trade growth, China's exports to the United States grew by $8 \%$, while Japanese exports declined by $2.4 \%$. Overall, since the start of the reform period, China's share of world trade has almost quadrupled. ${ }^{26}$

Although, China's exports have slowed since the Asian financial crisis, China's trade surplus continues to remain at a historically high level. In 1990 China's foreign exchange reserves was only US $\$ 40$ billion compared to Japan's US $\$ 100$ billion, however, by 1997 it increased to US\$111 billion in comparison to Japan's US $\$ 150$ billion. ${ }^{27}$ By the beginning of 1999, China's foreign exchange reserves had risen to US $\$ 150$ billion (equivalent to twelve to fourteen months of imports), thanks to robust trade performance and massive inflows of foreign capital which largely has taken the form of FDI. While FDI was negligible before 1978, by early 1999, foreign direct investment in joint ventures and wholly foreign-owned companies in China exceeded one-quarter of a trillion U.S. dollars, several times larger than cu-

\footnotetext{
${ }^{24}$ For a discussion of how China's preemptive devaluation contributed to the Asian financial crisis, see, Giancarlo Corsetti, Paolo Pesenti and Nouriel Roubini, What Caused the Asian Currency and Financial Crisis. New York: Stern School of Business, New York University. 1998.

25 The tax change meant that exporters could claim a refund of the VAT paid on inputs.

${ }^{26}$ Data compiled from World Bank, The World Development Report, 1998/99 (Washington, D.C: Oxford University Press, 1998); World Bank, The Chinese Economy: Fighting Inflation and Deepening Reforms (Washington, D.C.: The World Bank, 1996); International Monetary Fund (IMF), People's Republic of China: Recent Economic Developments, Staff Country Report n ${ }^{\circ}$ 97/71 (Washington, D.C.: IMF, 1997) and Zhongguo Jinrong Nianjian 1997 (Almanac of China's Finance and Banking 1997), Beijing: Almanac of China's Finance and Banking Editorial Department, 1997.

${ }^{27}$ The bilateral trade deficit of the United States with China has grown every year since 1985 . The Department of Commerce estimates that the trade gap grew by $15 \%$, reaching an all-time high of US $\$ 57$ billion in 1998. This is only a few billion less than the deficit registered with Japan, the United States' largest trade-deficit partner. See, Nicholas R. Lardy, “China's WTO Membership”, Brookings Policy Brief \# 47 (The Brookings Institution: Washington, D.C.: April 1999) : 1-8. Also, K.C. Fung and Lawrence Lau, “China's Foreign Economic Relations” Asia Pacific Research Center, Stanford University, May 1997; and various issues of Jinrong Shibao, China's leading financial newspaper.
} 
mulative FDI since World War II in Japan, South Korea and Taiwan combined. ${ }^{28}$ While China's large and growing reserves are matched by growing external liabilities, it is important to note that the bulk of these liabilities have long-term maturities, thereby making the external debt manageable. Moreover, China's foreign debt is at a low level compared with other Asian countries, with the debt/GDP ratio at $16.0 \%$ and the debt service ratio (i.e. debt service and percent of exports) at $8.5 \%$ in 1998 . As noted earlier, it also has long maturity, with shortterm debt making up only $19.7 \%$ of total debt in $1996 .{ }^{29}$ Given this, it is not surprising that China is amongst a handful of developing economies with an investment-grade rating on its sovereign external debt.

Finally, the evidence is unequivocal: the fruits of post-reform economic development has trickled down to broad segments of the Chinese population. For example, per capita consumption has increased four times for eggs and eight times for poultry, and the per person living space has more than doubled in the urban areas and nearly tripled in the rural areas. Average disposal per capita income has quadrupled since the early 1980 s, and Chinese households are saving on average some $40 \%$ of their income. Indeed, total household bank deposits measured against the GDP increased from less than 6\% in 1978 to more than $60 \%$ in 1998 . All this has helped to dramatically improve the living conditions of the majority of China's 1.3 billion inhabitants. The number of people living in absolute poverty has been substantially reduced from over 250 million to about 50 million in two decades. Life expectancy has increased from 64.3 years in the 1970s to 70.8 years in 1996, and infant mortality has dropped from over 50 per thousand in the 1970 s to less than 30 per thousand in the $1990 \mathrm{~s}^{30}$

By any standards post-reform China's economic achievements are enviable. Yet, to his credit China's amiable economic czar, Premier Zhu Rongji and his team of able technocrats have not being lulled into complacency. It seems they have grasped the essential lesson, the so-called "paradox" of the Asian financial crisis: that strong macroeconomic fundamentals while necessary, are not always sufficient for adverting currency crises or providing immunity from virulent contagion. Acutely aware

\footnotetext{
${ }^{28}$ Lardy, “China’s WTO Membership”, p. 3.

${ }^{29}$ This is sharp contrast to Indonesia with a debt/GDP ratio at $59.7 \%$ and the debt service ratio at $36.8 \%$, and short-term debt making $25 \%$ of the total debt in 1996. Similarly, Thailand in 1996 had a debt/GDP ratio at $50.3 \%$ and the debt service ratio at $11.5 \%$, with short-term debt making $41.4 \%$ of the total debt. World Bank, Global Development Finance (World Bank: Washington, D.C.: 1998): 1-20.

${ }^{30}$ Data is from China Statistical Yearbook, 1997. Beijing: China Statistical Publishing House; and Almanac of China's Population. 1997. Beijing: China Population Publishing House. The international poverty line as measured by the World Bank is based on US\$1-a-day. A recent World Bank study reports that "in absolute terms, the number of poor decreased by more than one-half in China" since the mid1980. World Bank, East Asia: The Road to Recovery. (World Bank: Washington, D.C.: 1998): 3. Also see, Zuliu Hu and Moshin S. Khan, "Why is China Growing so Fast", IMF Working Paper, n' 96/ 75, IMF Research Department, 1997; Joseph Stiglitz, "Second Generation Strategies for Reform for China" address given at Beijing University, July 20, 1998. (the World Bank website: www.worldbank.org), and Conghua Li and Pat Loconto, China: The Consumer Revolution (New York: John Wiley and Sons, 1998).
} 
of their economy's underlying structural weaknesses, they remain deeply concerned. ${ }^{31}$ As the next sections shows, their concerns are not misplaced.

\section{THE ECONOMY: UNDERLYING WEAKNESSES}

An important lesson of Mexico's peso crisis of 1994 and the Asian financial crisis was that a sound banking sector is the single most essential element of a healthy financial system. This is particularly relevant in transitional economies like the PRC where markets for corporate securities are limited and much of the lending unsecuritized. In such settings the banking sector are the main institutions that can (and must) effectively evaluate and monitor the risks and returns on financial intermediation, including the evaluation of borrowers creditworthiness, and to enforce financial contracts, loan recovery and the realization of collateral. Given these awesome responsibilities and its potentially far-reaching economic impact (both good and bad), it is critical that governments, including the central bank and related regulatory and supervisory agencies establish clear legal and institutional guidelines, implement adequate prudential supervision and regulation, including rules to ensure that there is no undue reliance on deposits many times larger than their capital, assets that are longer term and less liquid than liabilities, and accounting and auditing practices that are clearly defined and adhered. Such transparency is important so that the banks (and other financial institutions) cannot mask problems such as high proportion of non-performing loans, and, for banks involved in international transactions, that there exists a healthy balance between assets and liabilities denominated in different currencies exists. Asia's financial crisis vividly demonstrated that systemic problems in the banking and financial sector are accidents just waiting to happen — or more appropriately, waiting to "explode" without warning and quickly engulfing the economy as a whole. ${ }^{32}$

According to the Economist, China has "the worst banking system in Asia". ${ }^{33}$ Sorely lacking in professional competence and institutional autonomy and burdened with balance sheets that conceal much worthless assets, it is arguably the

\footnotetext{
${ }^{31}$ Barry Naughton, “China's Economy: Buffeted from Within and Without”, Current History (September, 1998): 273-8. Also see, Callum Henderson, Asia Falling: Making Sense of the Asian Crisis and its Aftermath (New York: McGraw-Hill, 1998).

${ }^{32}$ In Asia, once it became evident that many borrowers lacked the ability to repay their loans, depositors lost confidence in their banks' ability to meet their obligations, resulting in a "run" on the banks. This, combined with the fact that most banks were highly leveraged made them highly vulnerable to sudden bouts of instability.

${ }^{33}$ See, “The Worst Banking System in Asia” Economist, May 2, 1998: 65-7. Nicholas Lardy has also argued that China's banking sector is amongst the sickest in Asia. For details, see Nicholas R. Lardy, China's Unfinished Economic Revolution, and "China and the Asian Contagion" Foreign Affairs, Vol. 77, no 4, July/August 1998, pp. 78-88; Also see, The World Bank, China: Weathering the Storm and Learning the Lessons (World Bank: Washington, D.C.: 1999).
} 
Achilles heel of the entire economy. While the central reformers have instituted some important measures to create the institutional structures of a modern financial system, much more financial deepening is necessary to move China away from its present "socialist market economy" status. ${ }^{34}$ As during the era of central-planning, the central government continues to dominate other economic agents in the marketplace. Although, stock markets were established in Shanghai and Shenzhen 1990, and the activities of domestic (and some foreign ${ }^{35}$ ) commercial banks and nonbanking financial institutions, in particular, insurance companies, trusts and brokerage houses, security firms, Credit Cooperatives (both rural and urban) have gradually expanded, China's financial markets remains fundamentally bank dominated - and virtually all banks in China are state owned. In other words, although China has done away with the heavy reliance on budgetary financing of investment characteristic of the pre-reform era, and investment, particularly in the state sector is now financed primarily by banks, the banking institutions are state owned. Bank lending is huge in relation to GDP, while alternative channels of intermediation (whether private commercial banks, stock or corporate bond markets or capital markets) remain underdeveloped and plagued by government regulation and interference. Currently, state banks account for approximately nine-tenths of all financial intermediation between savers and investors, a ratio that exceeds that found in almost all other Asian countries. ${ }^{36}$ The banks near total monopoly and the lack of competition in the financial sector has stunted the development of capital markets resulting in systematic underpricing of loans by banks, not to mention inefficient financial intermediation, almost non-existent credit risk-assessment and diminishing rates of return for savers who have no real alternative to bank deposits.

Establishing the institutional framework of a modern financial system has been particularly difficult because economic decentralization has not been accompanied by parallel political and institutional reforms. Specifically, the fiscal and adminis-

\footnotetext{
${ }^{34}$ Most notably, while the banking and financial reforms have strengthened the system's ability to mobilize savings, it has been largely unsuccessful in the efficient use and allocation of these savings. For details, see, Xiaoping Xu, China's Financial System under Transition. New York: St. Martin's Press, 1998.

35 In 1997, two overseas banks, the Hong Kong and Shanghai Banking Corp. and the Industrial Bank of Japan was allowed to conduct local currency services in the Shanghai Pudong New Zone.

${ }^{36}$ According to one study, "Chinese banks are massive not only in terms of assets but also in terms of physical presence and people. The banks complicated, multi-tier organizational system extends from Beijing to the lowest districts and townships and villages throughout China. In 1996, the Industrial and Commercial Bank of China employed a total of 565,955 persons, including 121,140 at the township and village level in 38,219 branches, sub-branches and offices nationwide. The Agricultural Bank of China employed 538,780 in 65,870 branches, sub-branches and offices nationwide. The total employment of China's state-owned commercial banks, policy banks and the People's Bank of China at year-end 1996 was 1,915,947 persons in 157,365 branches, sub-branches and offices nationwide." Suffice it to note the enormous scale and scope of the banking operations make efficiency, accountability and risk control exceedingly difficult, it not impossible. See, Yabuki and Harner: 174-76.
} 
trative devolution gave provincial and local governments ${ }^{37}$ broad discretionary authority regarding economic investment and allocation without simultaneously enhancing the banking sectors regulatory and supervisory capabilities. Over time, this dense network of local political machines made of party officials, bureaucrats, managers and bankers who repay their special commercial privileges with political loyalty and financial kickbacks greatly undermined the central government's control over macroeconomic aggregates. An overview of this unfolding process is necessary for context.

During the Maoist period, the People's Bank of China (PBoC), founded in 1949 was the supreme bank in the country. While it served as both a central bank and government treasury (managed foreign exchange reserves, currency issuance and credit distribution), as well as a commercial bank (receiving deposits from households and enterprises and making loans), in practice the PBoC functioned mainly as an accounting body, its major task to take in household deposits (which were often the only asset households could hold) and to keep track of financial transactions that corresponded to allocations under the annual plan. The PBoC also directed and supervised the three major specialized banks: the Agricultural Bank of China (ABC), the People's Construction Bank of China (CCB), specializing in infrastructure finance, and the Bank of China (BOC), which served as China's foreignexchange bank, including all specialized subsidiary banks, non-bank financial institutions and insurance companies.

In the immediate reform period, the PBoC became accountable directly to the powerful State Council (or supposedly under the direct control of the reformers ${ }^{38}$ ), and some of its functions was devolved to the three specialized state-owned banks. The ABC began providing commercial banking services with emphasis on agricultural and rural industrial projects. A reconstituted CCB began financing fixed-asset investments, and the BOC continued its earlier functions. On January 1, 1984, in an effort to eliminate the PBoC's conflict of interest (inherent in its supervisory and commercial roles), and enhancing its ability to independently formulate and conduct monetary policy, it was granted the status of a central bank. As a central bank, the PBoC enjoys industry-level status. That is, it controls the money supply, determines interest and deposit rates, and handles foreign exchange reserves through its

\footnotetext{
${ }^{37}$ Local government id a broad category used here to imply both the intermediate (county and municipal) as well as township and village government.

38 The Chinese Communist Party Central Committee decides broad policy guidelines. These are then technically approved by the People's Congress, which is the highest organ of state power in China. Constitutionally, the State Council "is the highest organ of state administration" (Article 85). The State Council functions very much like the cabinet in a parliamentary system and is made up of the premier, the vicepremiers, the heads of government ministries or their equivalents, a secretary-general (to manage dayto-day work of the Council), an auditor-general (the chief financial administrator, and a few other top officials called "state councillors". The task of the State Council is to translate the broad policy guidelines into specific policies. Under the direction of the State Council, the State Planning Commission draws up long term (ten to twenty years), medium term (five years) and annual plans.
} 
division, the State Administration of Exchange Control. It also oversees banks' operations, using the credit plan to administratively control overall lending, and supervises the People's Insurance Company of China. Despite this, the PBoC's commercial activities were further devolved and transferred to the more "independent" (yet still government owned) specialized banks (the ABC, CCB and BOC), including a newly established fourth state-owned commercial or "specialized bank", the Industrial and Commercial Bank of China (ICBC) - which took over from the PBoC various commercial functions and now is the largest of the four state-owned banks.

Together the 'big four' state-owned banks account for about $75 \%$ of outstanding loans, have 150,000 branches and employ 1.7 million staff. ${ }^{39}$

Since 1986, the State Council has approved the establishment of a number of share-holding company-based commercial banks at both national and regional levels, as well as non-bank financial institutions such as credit cooperatives, insurance companies and international trust and investment corporations (ITICs). However, such seemingly prudent decentralization and the separation of powers did not make China's banking system any more "independent", transparent or efficient. To the contrary, while the PBoC continued to allocate the total credit target for each specialized bank, and individual targets for their respective branches, it left the monitoring to the regional and local $\mathrm{PBoC}$ branches $\mathrm{B}$ who were given wide discretion over lending decisions. However, given the fact that the local government officials have to be consulted before the center appoints a local bank governor (not to mention that the governor's promotion and future prospects is depended on the local governments evaluation), predictably allowed the various local and regional governments and political bosses to quickly exert much pressure on the respective branches of the PBoC for credit and loans. Furthermore, given the "soft budget" constraints faced by the specialized banks (which do not bear the risks of their loan decisions), and the fact that the $\mathrm{PBoC}$ sets interest rates which are below market rates, facilitated the quick issuing of loans and easy credit to support an array of SOEs (state-owned enterprises) both healthy and ailing, not to mention the local and regional governments appetite for speculative investments in real estate and other lucrative ventures.

By 1987 , it was painfully clear that the central government unable to keep the growth of money supply in check, or to prevent "soft lending" (loans made without reference to commercial criteria), simply lost control of the money supply. Local banks (which are local branches of the PBoC), and the specialized banks under pressure from local governments often exceeded lending limits laid down by the central authorities to subsidize the state enterprises and other pet projects (including illicit ones) in their localities. Indeed, it was not unusual for the state enterprises to automatically roll over due loans, not to repay their loans, for the banks to finance the deficits of local governments, including issuing loans at below the official interest rates and funding the junkets of public officials. Following Deng

${ }^{39}$ For details, see footnote 35. 
Xiaoping's promotional "southern tour" in Spring of 1992 during which he exhorted the need to accelerate economic reforms, the lid literally came off the money supply. As the central bank, unable to impose the necessary hard budget constraints on local banks passively moved to the sidelines, the regional and local governments and their cronies with both explicit and implicit support of the local banks embarked on a nationwide credit and investment binge. Many literally plundered the banks to fuel their desire to build even more skyscrapers and high-tech industrial parks in their town, not to mention the numerous wasteful and speculative activities. ${ }^{40}$ According to one account.

"As local governments sought accelerated development, the bank was obliged to provide capital indiscriminately [...] In one county of Hunan Province, for example, the vice county magistrate ordered the president of the local bank branch to turn over the bank's seal so the magistrate could issue letters of credit at will. It was common for local officials to force bankers to provide loans to favored projects" ${ }^{41}$

Predictably, the provincial and local governments pursuit of an excessive expansionary monetary policy not only fueled rising inflation (that jumped to some $37 \%$ in 1987-88), but also official corruption and graft. Indeed, China's experience questions the conventional view that decentralization improves efficiency, or that delegation of greater autonomy of local authorities or firm-level management will eradicate the "soft budget constraints". In fact, official corruption has reached epidemic proportions, and China earned the dubious distinction as one of the most corrupt countries in Asia B surpassing kleptomaniac states like Myanmar and Suharto's Indonesia. ${ }^{42}$

Finally, on January 1 1994, Vice-Premier Rongji stepped in to cool the overheated and unsustainable growth. Besides curtailing the runaway local bank loans and commercial credit by squeezing lending and suspending wasteful projects, he announced a series of bank and financial sector reforms. First, in an effort to loosen (if not break) the grip of the local and provincial leaders, all directors of regional branches of the PBoC were now to be appointed directly by Beijing. Second, all projects above a certain scale now had to be approved by the governor of the PBoC in Beijing. Third, in an effort to transform the state-owned commercial banks into real commercial banks, they were no longer required to carry out poli-

\footnotetext{
40 According to one school of thought, Deng Xiaoping often sided with the local and regional governments because he used them as a counterweight to the more conservative central ministries. See, Susan Shirk, The Political Logic of Economic Reform In China. Berkeley: University of California Press, 1993.

${ }^{41}$ Ding Jingping, China's Domestic Economy in Regional Context. Washington, D.C.: The Center for International and Strategic Studies, 1995: 20-1.

${ }^{42}$ Minxin Pei, “Will China become another Indonesia”, Foreign Policy, Fall 1999: 94-109.
} 
cy loans to the state-owned enterprises..$^{43}$ Rather all bank-financed government investment was now to flow through the three newly created policy banks: The State Development Bank (to provide loans for infrastructure and key industrial development), The Agricultural Development Bank (rural infrastructure and finances for crop purchases and food reserves), and The China Export-Import Bank (providing trade finance for machinery and electronic export). These three banks were now responsible for the provision of preferential loans to projects deemed important according to government policies. It was hoped that the separation of the banks commercial and policy lending functions, would prevent the transfer of funds earmarked for state projects to other projects. Fourth, the new rules prohibited the PBoC from issuing loans to enterprises. And finally, the so-called icing on the cake, the promulgation of the Central Bank Law and Commercial Bank Law (in March 1995), enhanced the independence to the ICBC, ABC, BOC and CCB to function as commercial banks, made them responsible for their profits and losses, and the requirement that they maintain an $8 \%$ capital adequacy ratio (none have met the requirement yet). Moreover, the law banned the $\mathrm{PBoC}$ from financing government budget deficits by printing money (deficits have to be financed by the sale of bonds), and from making loans to the various levels of central and local government agencies. The laws also gave power to the PBoC to implement monetary policy and exercise financial supervision over the other financial institutions.

These reform measures have given rise to a new type of banking institution (the so-called "share-ownership commercial banks" ${ }^{44}$ ), and helped bring the economy to a "soft landing" by reducing inflation to below 7\%, and removing some of the structural impediments and inefficiencies in the system. In March 1995, the National People's Congress (NPC) promulgated the Central Bank Law which provided the $\mathrm{PboC}$ with legal authority to exercise financial supervision over other financial institutions. Two months later the NPC passed the Commercial Bank Law on May 10 requiring the state banks to meet capital adequacy standards, besides imposing a much clearer system for classifying loans that brought commercial banking practices closer to those in the west. However, neither the reforms nor the Central Bank Law or the Commercial Bank Law of 1995 transformed the PBoC into a truly independent central bank. That is, although the PBoC has become more independent of the local and provincial governments, and like the U.S. Federal Reserve can set the reserve requirements of the banks, can buy and sell bonds and set the discount rate, and regulate the money supply, it nevertheless, still had to

\footnotetext{
${ }^{43}$ As commercial enterprises, these bank will now have to bear the responsibility for any losses incurred in their operations.

${ }^{44}$ In the "share-ownership commercial banks", various levels of government, Chinese institutions and in rare cases, individuals, holds shares. These banks include the Bank of Communications, the Shenzhen Development Bank, China Everbright Bank, Hua Xia Bank, China Investment Bank, China Merchant Bank, The Shanghai Pudong Development Bank, China International Trust and Investment Corp. (CITIC), Fujian Xingye Bank, Hainan Development Bank, China Minsheng Bank and the Guangdong Development Bank.
} 
operate under the watchful eye of the State Council. As in the past, all important bank decisions regarding the money supply, interest rates or exchange rates still had to be approved by the State Council. In light of this, Premier Zhu Rongji's claims that politically directed lending will end by the year 2000 sounds unduly optimistic.

Rather, the pervasive influence of the State Council, the PBoCs huge and procrastinating nomenklatura, its weak supervisory and disclosure framework, not to mention the meddling by recalcitrant political bosses, will continue to prevent it from exercising real discretion. Unlike an autonomous central bank, the PBoC is in no position to perform independent credit-risk analysis, or evaluate bank performance on the basis of normal commercial criteria. Nicholas Lardy notes that "China's largest banks are not subject to independent audits. Three of China's four largest banks do not even report their consolidated financial results, meaning that losses can be buried in subsidiary firms. Nonperforming loans are classified by more lenient standards than the international norm, impairing the value of the data in measuring bank performance". ${ }^{45}$ Suffice it to note, weak bank supervision combined with ineffective prudential regulation will continue to make it easier for the obstinate Communist party insiders, influential provincial and local bosses, and those with the ubiquitous guanxi connections to ingeniously determine who gets access to credit, besides channeling funds to themselves and their cronies through fraud, corruption and other lending irregularities. Although China's recent highpublicity anti-corruption campaign have witnessed the arrest of several high-profile businessman and bank executives, evidence also indicates that criminal financial activities, cronyism and favoritism continue to be rampant, and in fact may have worsened since the new laws were introduced. ${ }^{46}$

Currently, China's banking system is burdened with a huge build-up of nonperforming loans conservatively estimated at US $\$ 200$ billion or roughly $25 \%$ of the total GDP. ${ }^{47}$ Under pressure from international financial markets "for greater transparency" the usually stoic Dai Xianglong, the Governor of PBoC recently admitted (in January 1999), with uncharacteristic candor that the share of nonperforming loans in the portfolios of China's four largest state-owned banks had increased from $20 \%$ at the year-end 1994 to $25 \%$ at the year end $1997 . .^{48}$ Based on the internationally recognized $8 \%$ capital adequacy standard, all four of China's state-owned commercial banks are insolvent. Cognizant of the fact that the ratio of non-performing loans in South Korea was $17 \%$ on the eve of the crisis, the Governor and other reform-minded officials of the PBoC were quick to point out that only 5 to $6 \%$ of the loans are unrecoverable. However, keeping in mind that

\footnotetext{
${ }^{45}$ Lardy, "China and the Asian Contagion”, p. 79.

${ }^{46}$ Seth Faison, "China Points Finger at Culprit of the Week" New York Times (January 13, 1999): A8.

${ }^{47}$ Edward S. Steinfeld, “The Asian Financial Crisis: Beijing's Year of Reckoning”, The Washington Quarterly, vol. 21, n 3, Summer 1998: 37-51.

${ }^{48}$ Lardy, "China and the Asian Contagion”, p. 83.
} 
the so-called problem loans in China are not clearly recognized on banks' balance sheets (thereby making the scale of uncovered losses a major source of uncertainty), most analysts (including those in the IMF), are of the view that some $50 \%$ of the borrowers are already in default, and that a similar percentage of the loans nonredeemable. ${ }^{49}$ Despite the fact that in August 1998, the government provided a one-time capital injection of RMB 270 billion (US\$33 billion) in bank recapitalization program (financed by Treasury-bond issues), to bring the banks up to international adequacy standards, much more funds and strengthening of the supervisory and regulatory framework is needed. ${ }^{50}$ It is clear that a key precondition for a financial crisis - a fragile, if not, largely insolvent banking sector already exists. This makes a domestic banking crisis the most serious threat to macroeconomic stability in China.

The rapid deterioration of the banking sector is the direct result of what Nicholas Lardy has termed "China's unfinished economic revolution". Specifically, the reforms have not only failed to fundamentally restructure the country's some 300,000 ailing cash cows - the SOEs (state-owned enterprises ${ }^{51}$ ) - it has further exacerbated the problem by continuing to maintain the life support system to this ruinous vestige of Maoist central planning through the provision of large (if not extravagant) doses of subsidies. Yet, to be fair, the SOEs are still the primary providers of employment in the urban areas and care for the basic-needs of their workers, from housing and medical expenses to pensions. Concentrated in the 'rust-belt' in the north east, but present in virtually every production sector ranging from steel mills to coal plants and factories making machines, electronics or chemicals, the majority of these firms are loss-making and depend on government subsidies for survival. While the SOE sector accounts for a shrinking share of GDP, it continues to absorb a disproportionately large share of bank credit. According to Lardy, direct and indirect subsidies to the SOEs and the banking system may now be costing the country some $10 \%$ of its GDP. It is these so-called concessionary indirect "soft credits" or "policy loans" from state banks to SOEs, implicitly guaranteed by the government (as well as granted under preferential terms) have over time reduced

\footnotetext{
${ }^{49}$ Reuters News Service, “Full Text: China’s Central Bank Governor’s Speech” January 27, 1999. Lardy, China's Unfinished Economic Revolution (pp. 115-7), notes that the share of nonperforming loans that is accounted for by the most impaired categories of loans has increased. Specifically, the sum of the share of loans that are outstanding to firms that have already gone through bankruptcy and been liquidated without the bank recovering their loans, the so-called "dead loans", and loans that are two years or more overdue (i.e. "doubtful loans") increased by at least half between year end 1994 and year end 1997.

${ }^{50}$ According to "Moody's Investor Service estimates, China needs RMB 1000 billion, or $12 \%$ of its GDP, to clean up the bad loans". See, Louise do Rosario, "Trouble Spots: China”, The Banker, October 1999: 93.

${ }^{51}$ Before reforms, China's industrial economy resembled that of the former Soviet Union. SOEs accounted for $78 \%$ of all industrial output, almost all urban employment and $91 \%$ of investments in fixed assets. Of the estimated 300,000 SOEs, roughly 5,000 to 6,000 are regarded as "large scale". The rest are either "medium" or "small".
} 
the banks to little more than conduits for cheap credit to the SOEs. It is no surprise that borrowing by the SOEs (measured by the value of loans outstanding) have increased by 40-fold between 1978 and the end of 1997.

Yet, the unwieldy SOEs insatiable appetite for subsidized credit is not reflected in their poor performance. Currently, SOEs account for less than $30 \%$ of the industrial output, compared to $80 \%$ fifteen years ago, yet consume almost $75 \%$ of national industrial investment. ${ }^{52}$ Factory-capacity utilization rates for major industrial products of SOEs have fallen below $60 \%$, while the industrial SOEs profits have declined precipitously from $6 \%$ of GDP to less than $1 \%$ in the past decade. ${ }^{53}$ While asset stripping (the illegal transfer of state assets to non-state ownership), and the customary practice by the central, provincial and even local governments to conveniently saddle the SOEs with excessive social responsibilities (including the responsibility to provide cradle-to-grave services to the estimated 112.4 million SOEs workers ${ }^{54}$ ), have taken a toll on performance, Lardy notes that the major reason for the SOEs moribund performance is the lack of fundamental change in ownership and in corporate governance. Besides overproducing an array of unwanted goods, a growing number of SOEs have been losing money. Approximately $50 \%$ perennially incur net losses compared to one-third just a decade ago. As of October 1997 roughly $46 \%$ of SOEs were in the red and losses of these enterprises made up $57 \%$ of the total. Indeed, available data shows and a growing number of SOEs have accumulated unmanageable debt to equity ratios of between 400 to $700 \% .{ }^{55}$ In effect, the majority of the SOEs, unable to amortize their debt, and through reckless borrowing have zero or negative net-worth today. They have not only made themselves technically insolvent, but have also left the banking sector hopelessly burdened with large portfolios of non-performing, indeed, non-redeemable loans. ${ }^{56}$ It is important to note that the bulk of the banks SOE loans are still performing only because of government guarantees on banks and government subsidies of SOEs. Were these to cease, interest payments on SOEs would cease, rendering the banks illiquid. Asia's financial crisis illustrates that in an economic slowdown the highly leveraged SOEs have the potential to create major liquidity problems for the banks. A domestic banking crisis could push China into a deep

\footnotetext{
52 This sharp decline is due in large part to the fact that since 1978 Beijing has allowed the non-state sector to compete with SOEs.

${ }^{53}$ According to Naughton, “China's Economy”, “Overall, industrial SOE profits sank to 45 billion yuan in 1997 (after deducting losses), or only 0.6 percent of GDP.

54 This figure is for 1996. State Statistical Bureau, China Statistical Yearbook (Beijing: China Statistical Publishing House, 1997).

${ }^{55}$ Harry G. Broadman, "The Chinese State as Corporate Shareholder", Finance and Development, vol. 36, $\mathrm{n}^{\circ}$ 3, September 1999, pp. 52-55. Also, World Bank, China's Management of Enterprise Assets: The State as Shareholder (World Bank: Washington, D.C., 1997).

${ }^{56}$ According to Steinfeld, “The Asian Financial Crisis”, "In 1997, total net assets of the banking system were listed officially at RMB 317 billion, less than 20 percent of the estimated value of non-performing loans in the system".
} 
recession, and could eventually force the government to devalue the currency. The cost of bank bailouts under such conditions will be astronomical.

Yet, if by tomorrow the SOEs were to miraculously honor all their financial obligations, the banks position would continue to remain weak. It is because, like Thailand, Malaysia, South Korea, Japan and Indonesia (just to name a few), Chinese banks have played a lead role in creating "asset bubbles", especially in the volatile real estate and construction sectors. ${ }^{57}$ During the early to mid 1990s, when "a casino mentality" 58 gripped the country, banks and other financial institutions imprudently funded massive property developments throughout China. First-class office spaces, luxury villas, ostentatious townhouses and apartments sprang up almost overnight, not only in major cities like Beijing, Shanghai and Shenzhen, but also in the many smaller provincial and coastal county towns. Perhaps, nowhere was the transformation as stunning as in Shanghai. The so-called "Shanghai bubble" transformed this once drab city into one of the world's glamour metropolis. By yearend 1995, Shanghai boasted over a thousand skyscrapers, (including some one hundred five-star hotels), about 13.5 million square feet of office space in 1997 (an unprecedented five times the 2.7 million square feet in 1994), and a "hot" real estate market that was adding stock at a faster rate than New York city..$^{59}$ However, the boom was relatively short-lived. By late 1996 the bubble had burst, in large part because of inefficient allocation of resources and overcapacity. By first-quarter 1999, some 350 million square meters of office space stood empty, and real estate prices slid to below $50 \%{ }^{60}$ For many banks and their subsidiaries such as the freewheeling ITICs and SOEs, with heavy exposure to real-estate construction and speculation, this has meant a further deterioration in their balance sheets. ${ }^{61}$ However for an increasing number, it has meant bankruptcy. The collapse of the country's second largest financial-trust company, the Guangdong International Trust and Investment Corporation (GITIC) in October 1998 sent an ominous sign. The GITIC had to declare bankruptcy when it was revealed that its debt totaled $\$ 4.4$ billion, compared to only $\$ 2.9$ billion in assets. In October 1998, the government announced the closure of GITIC sending shock waves to Hong Kong where many banks claimed they had lent to GITIC because Guangdong provincial government guaranteed the loans. ${ }^{62}$

\footnotetext{
${ }^{57}$ Joshua Cooper Ramo, “The Shanghai Bubble” Foreign Policy, Summer 1998: 64-75.

${ }^{58}$ I owe this term to Gao Xiqing, vice-chairman of the China Securities Regulatory Commission.

${ }^{59}$ Figures are from Lardy, "China and the Asia Contagion”, and Ramo, "The Shanghai Bubble”.

${ }^{60}$ John Pomfret, "China set to Tackle Economic Woes”, The Washington Post, January 16, 1999: A21.

${ }^{61}$ Non-bank financial institutions such as the ITICs are sponsored by individual provinces to help them raise capital overseas, bypassing the supervision of central authorities. For many of the ITICs the value of their speculative overseas equities and real estate investments collapsed during the Asian crisis.

62 Pomfret, "China set to Tackle Economic Woes". GITIC is not the only major financial company to collapse. In early 1999, Hainan Development Bank also collapsed under a mountain of bad debt.
} 


\section{EXPLAINING CHINA'S RESILIENCE}

One of the ironies of Asia's financial crises: Why, China beset with many of the same fatal flaws that sent the dynamo Asian economies crashing like dominoes, survived the crisis with barely a bruise? In other words, what explains China's remarkable immunity to the "Asian flu"?

First, unlike virtually all other Asian economies directly affected by the financial turmoil, the RMB is not convertible for capital account transactions. ${ }^{63}$ Instead, it is only convertible on the current account (i.e. official documentation of a legitimate trade or other approved transaction is required to change money). This, partial convertibility of the RMB makes it extremely difficult for speculators to take any short position against the RMB or to place large leveraged bets for or against the currency - since there is no forward market that speculators can use to attack the RMB. Also, the PBoC by requiring everyone to buy or sell foreign exchange or foreign currency denominated financial assets to enter the exchange market operating through designated banks has inadvertently given itself greater flexibility in responding to balance of payments problems. This is because the foreign exchange market is not open to any purchase of foreign exchange for capital account transactions. Large RMB spot transactions require the pre-approval of the State Administration for Foreign Exchange (SAFE). The SAFE approval requirements and related limitations on foreign participation in PRC equity markets have translated into low levels of portfolio investment. A combination of all this has made China less vulnerable to contagion and domestic or externally driven speculative attacks.

Second, in the pre-crisis high-performing Asian economies, a mix of pegged exchange rate, heavy sterilization and no capital controls to discourage liquid shortterm flows, encouraged heavy external borrowing, in particular, of ever increasing amounts of "hot money" in the form of short-term credits. Within a short period of time such practices not only created an excessive exposure to foreign exchange risk in both the financial and corporate sectors (the result of growing mismatches in the structure of lending and borrowing), it also had negative effects on foreign direct investment and portfolio investment - which sharply declined in share in total private capital flows. However, in mid-1997, approximately $70 \%$ of capital flows to China were in the form of FDI. An estimated US $\$ 200$ billion, it was almost twice the level of China's officially reported foreign borrowing. ${ }^{64}$ FDI with their much longer-term maturities and manageable debt-service ratios (given its rela-

\footnotetext{
${ }^{63}$ Capital account convertibility can be broadly defined as the freedom from quantitative controls, taxes and subsidies that affect capital account transactions between residents and non-residents. Examples of such transactions include all credit transactions between residents and non-residents, including trade and non-trade related credits and deposit transactions, and transactions in securities and other negotiable financial claims.
}

${ }^{64}$ Lardy, "China and the Asian Contagion". 
tively little exposure to private debt denominated in foreign currency), are far more stable and less susceptible to sudden reversals in direction due to negative monetary shock or investor panic. It made China less vulnerable to a speculative-led liquidity crisis. Equally important, China's massive geographic size and market potential allowed it to keep capital account closed and still enjoy sustained inflows of FDI

Third, unlike pre-crisis Thailand, South Korea, Indonesia or Malaysia which were heavily burdened with short-term debt liabilities. As noted earlier, approximately $90 \%$ of China's external debt is medium to long term - the bulk of these taking the form a direct investment, mostly joint ventures, that are highly illiquid and difficult to withdraw quickly. In addition, China (unlike its Asian neighbors) does not have a banking and financial system with substantial foreign debts denominated in foreign currencies. By contrast, nearly all of South Korea's external exposure was in so-called portfolio form (mostly bank debts and bonds), some two-thirds of it short-term. Thus, in the case of China, foreign lenders could not call in their loans every three to six months. Such relative stability greatly reduced the possibility of an immediate banking crisis. Also, China has less capitalization through the stock market and less foreign equity investment to be repatriated by nervous investors if market sentiments change. Finally, since the banks in the PRC are state-owned, their bad debts are simply government debts, not private debts. Moreover, the country's bad debts in the banking system are denominated in RMB and not US dollars. Considering the fact that the taxation ability of the central government is about onehalf of that in the developed countries, the burden of servicing the government debts as a share of the government budgetary expenditure is still comparable to other countries and still manageable. These strengths gave China a greater breathing space to make the necessary policy adjustments during the crisis.

Fourth, China has experienced trade and current account surpluses since 1994. China's healthy current account surpluses (some $\$ 30$ billion), massive trade surpluses and a formidable "war chest" in foreign exchange reserves (totaling some $\$ 150$ billion in mid-1999), and second in size only to Japan, reduced the pressure to devalue the currency or raise interest rates. Moreover, there was no overhang of shortterm debt that could not be repaid easily out of foreign exchange reserves when debt was not rolled over. While, there was an outflow of direct foreign investment, the foreign assets remained in place sufficiently that foreign exchange reserves were not threatened with depletion. During the period January to June 1998, although export growth was slowing, import growth was declining even more.

Fifth, unlike most hard-hit Asian economies, China does not suffer from significant exchange rate misalignment. As noted earlier, after depreciating in the early 1990s, the RMB has appreciated considerably in recent years in real terms. Even after the 1997 devaluations of its neighbors, a change of merely $10 \%$ could return the RMB to its pre-1994 value in trade-weighted terms. Yet, as will be discussed later, if the other Asian currencies sink lower, China's trade competitiveness will follow, especially in the absence of concomitant productivity growth. Yet, it is important to note that China's export growth may not be adversely affected by 
devaluations elsewhere in Asia. Not only China exports a more diverse range of products, its labor costs are below the average for the Asian region. Regional devaluations may reduce the labor cost differential relative to China, but may not eliminate it. In industries such as textiles and garments, Southeast Asia is unlikely to take away significant market share from China.

And, sixth, the sheer size and diversity of the Chinese economy helped it to better withstand the crisis. Because China's domestic market is huge, the Chinese industries (in relative terms) are less dependent on the world markets. Exports as a share of GDP are lower for China than most of the crisis-affected Asian economies. In smaller economies, firms tend to rely excessively on exports and/or concentrate on a relatively narrow range of industries. In contrast, China's size and diversity has allowed for the development of a highly varied export structure. This enabled China to remain competitive in labor-intensive industries, while developing its high-technology industries.

\section{THE ACHIEVEMENTS AND CHALLENGES AHEAD}

The good news is that strong economic growth continued in the first half of 2000 . The GDP grew by $8.2 \%$, driven mainly by domestic consumption and sustained fiscal stimulus spending. Due to the pickup in domestic consumption, the deflationary trend of the previous two years was arrested in the first half of 2000 . Further, with the recovery in Asian economies, the PRC's external trade has improved substantially. It is important to note that with the onset of the 1997 Asian financial crisis, the Chinese government fixed nominal parity with the US dollar. Although this was initially in defense of Hong Kong and its currency board system, the Chinese government has held to its commitment beyond the Hong Kong financial crisis. Nominal parity with an appreciating US dollar in a period of low inflation ensured real appreciations against almost all of China's trading partners. However, deflation in China has ensured that a real depreciation has been enjoyed relative to the US and more recently, against European Union. In spite of the reduced competitiveness of Chinese exports relative to those from the crisis affected countries, the value of Chinese exports has continued to grow. Exports, which rose by $6.2 \%$ in 1999 , surged by $38.3 \%$ during the first half of 2000 . Thus, the PRC will post a current account surplus in 2000 - roughly close to the US $\$ 16.0$ billion surplus achieved in 1999. ${ }^{65}$

Despite these positive trends, there is wide consensus that the problems in China's banking and financial sectors, and within the SOEs are not sustainable and needs to be resolved expeditiously. Suffice it to note that the international position of China still hinges on the future of the banking system and on the prospects of further financial market liberalization. While Asia's financial crisis exacerbated

${ }^{65}$ Asian Development Bank, 2000, Asian Development Outlook 2000: Update. Manila, p. 23. 
China's banking problems (in large part because the falling demand from Southeast Asia and Japan for Chinese products and steeper competition from both foreign and domestic private sector products have reduced the SOEs income and ability to repay loans), as noted earlier, the banks must be further re-capitalized and opened to competition (to increase their holdings of commercially viable, performing loans), and their prudential supervision strengthened. It is very unlikely that a significant portion of the loans to the SOEs will ever be repaid. Given this, the central dilemma facing the Chinese leadership is how to phase out the loss-making SOEs without precipitating massive unemployment. Ultimately the SOEs must be restructured through either hard-budget constraints, downsizing or outright closure. Since such measures has the potential to displace millions of SOE workers who rely on the SOEs not only for employment, but medical, housing and education benefits, it is important to begin the reform process before a crisis hits. ${ }^{66} \mathrm{And}$, a crisis of internal makings in not far-fetched. For example, should the government's willingness to bail out even one Chinese bank come into doubt, or when savers lose confidence in the government's implicit guarantee of their bank deposits, or should foreign banks become an easy alternative after China joins the WTO (World Trade Organization), millions of ordinary Chinese might pull their deposits out of banks, including banks that were previously sound but would become unsound as a result. The PRC leadership is well-aware that the availability of alternative financial assets would tempt depositors to withdraw their funds from bank savings account, thus exposing the insolvency of much of the banking system. The fact that China's banks rely heavily on savings deposits of households (households' share in total domestic saving increased from 24 percent in 1979 to above 70 percent in 1997), the resulting bank run would have disastrous consequences. ${ }^{67}$ Among other things, a bank run would force a large number of SOEs to close. While WTO membership may bring FDI back, it will also put unprecedented competitive pressure on the SOEs and their products. In short, what may began as a banking crisis can quickly become a economy wide crisis, with severe socioeconomic consequences.

During the Ninth Party Congress in April 1998, China's leaders candidly acknowledged the daunting economic challenges the country faced. The highlight of the Congress was when Premier Zhu Rongji sternly announced that the problems associated with money-losing SOEs and failing banks will be solved within three years through an accelerated program of closure, privatization and mergers. While some progress has been made in the area of SOE reform, much more needs to be done. Specifically, small and medium-sized firms have undergone de facto privatization - or privatization in the form of management buyouts and the sale of shares to employees. In regards to the large SOEs, the Chinese authorities favor the Kore-

\footnotetext{
${ }^{66}$ Some have suggested that the government could use fiscal stimulus by spending funds on infrastructure and residential housing to revive domestic demand and soak up unemployment.

${ }^{67}$ Figure from Yiping Huang, 1999, “Challenges for China's Financial Reform”. paper presented at China Update Conference, The Australian National University.
} 
an model. That is, there is strong ideological support for retaining state ownership in key strategic industries, and support for chaebol type conglomerates. Until the Asian crisis, the PRC leadership believed that in taking advantage of economies of scale (through firm mergers and industry consolidation), would increase efficiency to address the problems facing the SOEs. Indeed, the creation of such conglomerates was seen as a short-cut method of reforming (or restructuring) the SOEs. The financial crisis in general, and the massive failures of chaebols vividly demonstrated that the Korean model is no panacea.

The leadership of the PRC is cognizant of the fact that the creation of a modern financial system is essential if China is to achieve the central goal of its economic reform program: improving the efficiency with which capital is allocated and utilized. Without doubt, the most critical step in improving efficiency of resource allocation and utilization is the creation of a modern banking system. As noted earlier, the reasons for this is straightforward. First, with their share of financial intermediation totaling some nine-tenths, China's financial system revolves around banks. And second, the development of capital markets obviously depends on a strong commercially oriented banking system to process payments and act as custodians. Since early 1998, in the area of bank reform, state-owned commercial banks have been deepening their operations and management systems, merging the provincial banks with provincial city branches, and improving loan classification and provisioning regulations. For example, banks have been given freedom to appraise investment projects independently, using international risk management and prudential norms. Also, the business practices of banks are being improved by the classification of nonperforming loans according to international standards, the adoption of international accounting standards, and the publication of consolidated accounts, including of subsidiaries so that portfolios can be assessed properly.

In March 1998, the Ministry of Finance issued 270 billion yuan (roughly US $\$ 32$ billion) of special treasury bonds designed to recapitalize state-owned commercial banks, enabling them to meet the $8 \%$ capital adequacy ratio required under the Basle Agreement. ${ }^{68}$ Indeed, China needs to create a capital market to supplement the role of banks in the allocation of capital. Bonds can serve as a more effective instrument than bank loans in providing long-term capital for infrastructure and other projects with long gestation periods. Moreover, equity markets can supplement bank financing for enterprises, thereby enabling them to achieve a more balanced financing structure. Also, the government has set up asset management companies (AMCs) to take over nonperforming loans from the banks, and to assess the credit expansion of banks by asset-liability ratios rather than through the centrally directed credit plan. However, as a recent (September, 2000) IMF report notes, "the AMCs activities to date has largely been book-keeping transactions [...] A key

\footnotetext{
${ }^{68}$ Because the bond issue has no budgetary implications, it effectively shifts these costs to future years. There is also the question as to whether the sum is large enough to permit a sound separation of good and bad debts.
} 
element to the success of the AMC strategy will be to ensure restructuring of the enterprises in which the AMCs become stakeholders [...] the AMCs needs to be provided with the skills and incentives to discharge their responsibilities, and to ensure that their financial positions are soundly based". ${ }^{69}$

In 1998, in an effort to immunize the PBoC branches from local pressure to lend and strengthen the independence of the Central Bank, the People's Bank of China canceled 30 provincial branch banks and then established 9 regional branches. ${ }^{70}$ The nine branches are to be directly supervised by Beijing, which will hold them responsible for implementing monetary policy, collecting financial information, supervising foreign exchange activities and overseeing clearing and payment settlement in their respective geographic regions. In other words, the People's Bank will now operate along similar lines as those of the US Federal Reserve System. Finally, the PBoC has increased the number of pilot cities for RMB business of foreign banks, approving Shenzhen City to be the second city where the foreign banks are permitted to open RMB business. Foreign banks now enjoy the same status with Chinainvested banks as members of national interbank transaction market and are free to choose transaction counterparts to conduct bond dealings and bond repos. Foreign banks are also encouraged to provide consortium loans with China-invested banks. By August 1999, 25 foreign banks have been permitted to run RMB business. In early 2000 , the $\mathrm{PBoC}$ canceled the regional restrictions on foreign banks, allowing them to establish branches in all central cities. ${ }^{71}$ The authorities have also taken steps to reform the non-bank financial institutions. A number of institutions have been closed down, most notably GITIC, China's second largest trust and investment company. In December 1998, the National People's Congress promulgated the Securities Law to punish illegal financial activities. In the SOE sector, the basic policy is to divest small, non-strategic companies completely and to restructure the larger ones through mergers, public ownership, hard budget constraints, or other means. The prospect of bankruptcy or the shutting down of loss-making firms is not excluded, although the government will likely apply such measures only if all other means have failed. It is hoped that the reforms will establish a modern enterprise system based on a clear separation of the state's ownership of enterprise from their management. Overall, progress in this difficult area has been slow and incremental. To date, some efforts have been made to move small enterprises out of the state sector and commercialize large enterprises. Besides reducing some of the excess capacity and overstaffing, the authorities are still look-

\footnotetext{
${ }^{69}$ IMF, 2000, IMF Concludes Article IV Consultation with China. Public Information Notice, No. 00/ 71. September 1.

${ }^{70}$ The nine regional branches are located in Shenyang, Tianjin, Jinan, Nanjing, Shanghai, Guangzhou, Wuhan, Chengdu and Xi'an.

${ }^{71}$ For further details, see Huang Fanzhang and Xu Zhong, "Carrying forward Financial Reform in China”, Journal of Asian Economics, vol. 11, 2000: 15-22.
} 
ing at ways to develop and strengthen the social safety nets in order to protect workers adversely affected by the reforms.

Despite these reforms, China still has a long way to go. It is important to recognize that the implementation of such an ambitious reform agenda is by no means guaranteed. Specifically, will the political and economic strains of a quasi-Leninist state push the reformers to backtrack? Consider for example the double-entendre: Although, Premier Zhu Rongji in 1998 abolished the so-called "credit plan" (which regulated annual bank lending by quotas and ceilings), and allowed the banks to make loans on the basis of stringent standards of accountability and creditworthiness, in 1999 the government once again ordered these banks to help fund the economic stimulus with loans to SOEs - loans that will most likely never be repaid. Or will the government take the other easy way out: through a competitive devaluation of the currency, rather than via the more prudent (and painful) reforms designed to increase productivity via internally generated efficiencies. Although Premier Zhu and PBoC Governor Xianglong, including other senior officials have repeatedly stated that the renminbi will not be devalued, the pressures for competitive devaluation is quite real.

First, although China received much praise for not devaluing the RMB during the crisis, the price paid has been declining international competitiveness and growing balance of payments pressure. The deep currency devaluations elsewhere in Asia, coupled with the overall economic slowdown, in particular, the continuing sluggishness of the Japanese economy is having an adverse impact on China's export competitiveness. ${ }^{72}$ Exports are crucial to China's economic growth and employment - and the crisis-affected countries accounts for about $60 \%$ of China's merchandise exports. While it is true that the fall in the Korean won has had little impact on China's exports because Korean products are more capital and technology intensive, there is little doubt that the commodity mix of China's exports (dominated by labor-intensive products) have been hurt (and will continue to suffer) by competitive devaluations in Indonesia, Thailand, Malaysia and the Philippines. ${ }^{73}$ Few economists now believe that the current policy of nominally pegging the value of the RMB to the US dollar is the optimal exchange rate policy for China. Rather, most agree that a managed float or some kind of basket peg in which non-dollar currencies, in particular, the yen receives a significant weight would be preferable. It is estimated that a modest $5 \%$ real depreciation of the RMB would increase China's trade surplus by around US $\$ 20$ billion. ${ }^{74}$ Will this push China to move to a new

\footnotetext{
${ }^{72}$ In the first three months of 1999 , total exports dropped nearly $8 \%$ from the year earlier period while imports rose $11.5 \%$. As a result, the first quarter trade surplus narrowed to US $\$ 4.3$ billion down $60 \%$ from the year earlier. For details, see James Leung, “The Downward Spiral” Asian Business, June 1999: 31.

${ }^{73}$ China's exports grew by just $0.5 \%$ in 1998 , compared with $20.9 \%$ the year before. Forecasts point to further export declines in 1999-2000.

${ }^{74}$ Marcus Noland, “Asian Economic Recovery”, Washington, D.C.: Institute for International Economics, Policy Paper, 1999. (www.iie.org)
} 
exchange rate policy by devaluing the RMB and reestablishing its competitiveness? An early conventional account has so far proven to be incorrect:

Although the Chinese government announced that the RMB would not be devalued, there are strong doubts. Chinese leaders and economists agree that an RMB devaluation would have little effect on China's exports, but may cause a regional currency depreciation cycle, which would hurt the recovery of affected economies. But, there is a price to be paid to maintain the RMB value. Though devaluation may do little to improve exports, it would adversely affect imports [...] With a large foreign exchange reserve and trade surplus, the Chinese government probably has enough financial wherewithal to maintain the RMB exchange rate at least until early 2000 , if not beyond. ${ }^{75}$

And second, can the Chinese government carry out the necessary "deep" restructuring challenges in the banking and SOE sector without maintaining the growth rates of the critical 8 to $9 \%$ ? It should be noted that even respectable growth rates of $6 \%$ and $7 \%$ may not be sufficient. Even an $8 \%$ growth rate is barely sufficient to maintain the much-cherished cradle-to-grave "iron rice bowl" for those with jobs, let alone generate employment for the swelling and increasingly impatient urban labor force. Indeed, unemployment has been increasing, and the imperative to maintain aggregate demand to absorb displaced labor and new entrants into the work force is great. No doubt, for most part of 1999, the government has been preoccupied with reviving the sluggish economy. It slashed interest rates twice, in January and June, bringing the rate for a one-year deposit down to $2.25 \%$, and embarked on a Keynesian-style 100 billion yuan (US\$12 billion) public spending program, funded by issuing a record volume of Treasury Bonds. No doubt, such public works program will help create employment in the short term. Yet, in order to provide continued stimulus to output growth, public investment must only remain at a high level, but must continue to grow steadily. Given China's relatively low level of tax revenue and undeveloped bond market, financing further large scale investment surges will be difficult.

The big question is how will China balance the conflicting concerns. Will Beijing's recognition of its regional responsibility (not to devalue), prompt it to continue to rely on fiscal and monetary tools to stimulate domestic demand, or will domestic economic and political pressures take precedence forcing devaluation to increase exports? While devaluation could re-ignite financial market turmoil and another round of competitive devaluations, it is important to note that RMB devaluation is an easy way to stimulate China's slowing economy. After all, relaxation of lending, by itself, is unlikely to boost the economy given the large volume of

\footnotetext{
75 Brookings Institution Policy Brief. 1999. The Economic Debacle in Northeast Asia: Economic, Political and Social Legacies. Washington, D.C.: The Brookings Institution.
} 
non-performing loans. Also, lower infrastructure and labor costs and the greatly improved regulatory and supervisory banking systems in Southeast Asia and South Korea may result in FDI bypassing China. Indeed, investment capital originating from Hong Kong, Taiwan, Singapore and Japan has fallen sharply. Their combined share of total FDI in China has shrunk to $45 \%$ in 1998 from $68 \%$ in $1994 .{ }^{76}$

Finally, in November 1999, after 14 years of negotiation, China and the United States reached a bilateral agreement that paves the way for China to join the WTO. The Chinese regard joining the WTO as their most important economic reform in 20 years. China is expected to officially join the WTO in late 2000. Over the long term, the country's adherence to WTO commitments should lead to significant efficiency gains and higher consumer choice. However, during the initial years, accession to WTO will pose several challenges in key sectors such as agriculture, manufacturing, banking, insurance and telecommunications. Moreover, WTO obligations will require the government to further reform its laws and regulations to (i) honor the immediate obligations of being a WTO member, (ii) accord equal treatment to domestic and foreign enterprises as required by the national treatment clause, and (iii) improve the legal framework, and the supervisory and regulatory systems to cope with a more competitive environment. How will China react to these challenges? Only time will tell.

${ }^{76}$ James Leung, “The Downward Spiral”, p. 32. 